\title{
Plant functional type classification for earth system models: results from the European Space Agency's Land Cover Climate Change Initiative
}

\author{
B. Poulter ${ }^{1,2}$, N. MacBean ${ }^{1}$, A. Hartley ${ }^{3}$, I. Khlystova ${ }^{4}$, O. Arino ${ }^{5}$, R. Betts ${ }^{3}$, S. Bontemps ${ }^{6}$, M. Boettcher ${ }^{7}$, \\ C. Brockmann ${ }^{7}$, P. Defourny ${ }^{6}$, S. Hagemann ${ }^{4}$, M. Herold ${ }^{8}$, G. Kirches ${ }^{7}$, C. Lamarche ${ }^{6}$, D. Lederer ${ }^{6}$, C. Ottlé ${ }^{1}$, \\ M. Peters ${ }^{7}$, and P. Peylin ${ }^{1}$ \\ ${ }^{1}$ Laboratoire des Sciences du Climat et de l'Environnement, LSCE-IPSL (CEA-CNRS-UVSQ), 91191 Gif-sur-Yvette, France \\ ${ }^{2}$ Department of Ecology, Montana State University, Bozeman, Montana 59717, USA \\ ${ }^{3}$ Met Office Hadley Centre, FitzRoy Road, Exeter, EX1 3PB, UK \\ ${ }^{4}$ Max Planck Institute for Meteorology, Bundesstrasse 53, 20146 Hamburg, Germany \\ ${ }^{5}$ ESA-ESRIN, 00044, Frascati, Italy \\ ${ }^{6}$ Université catholique de Louvain, Earth and Life Institute, 1348 Louvain-la-Neuve, Belgium \\ ${ }^{7}$ Brockmann-Consult GmbH, Max-Planck Str. 2, 21502 Geesthacht, Germany \\ ${ }^{8}$ Laboratory of Geo-Information Science and Remote Sensing, Wageningen University, Droevendaalsesteeg 3, \\ Wageningen $6708 \mathrm{~PB}$, the Netherlands
}

Correspondence to: B. Poulter (benjamin.poulter@montana.edu)

Received: 22 November 2014 - Published in Geosci. Model Dev. Discuss.: 21 January 2015

Revised: 27 June 2015 - Accepted: 30 June 2015 - Published: 31 July 2015

\begin{abstract}
Global land cover is a key variable in the earth system with feedbacks on climate, biodiversity and natural resources. However, global land cover data sets presently fall short of user needs in providing detailed spatial and thematic information that is consistently mapped over time and easily transferable to the requirements of earth system models. In 2009, the European Space Agency launched the Climate Change Initiative (CCI), with land cover (LC_CCI) as 1 of 13 essential climate variables targeted for research development. The LC_CCI was implemented in three phases: first responding to a survey of user needs; developing a global, moderate-resolution land cover data set for three time periods, or epochs (2000, 2005, and 2010); and the last phase resulting in a user tool for converting land cover to plant functional type equivalents. Here we present the results of the LC_CCI project with a focus on the mapping approach used to convert the United Nations Land Cover Classification System to plant functional types (PFTs). The translation was performed as part of consultative process among map producers and users, and resulted in an open-source conversion tool. A comparison with existing PFT maps used by three earth sys-
\end{abstract}

tem modeling teams shows significant differences between the LC_CCI PFT data set and those currently used in earth system models with likely consequences for modeling terrestrial biogeochemistry and land-atmosphere interactions. The main difference between the new LC_CCI product and PFT data sets used currently by three different dynamic global vegetation modeling teams is a reduction in high-latitude grassland cover, a reduction in tropical tree cover and an expansion in temperate forest cover in Europe. The LC_CCI tool is flexible for users to modify land cover to PFT conversions and will evolve as phase 2 of the European Space Agency CCI program continues.

\section{Introduction}

Terrestrial ecosystems are characterized by a wide variety of biomes covering arctic to tropical vegetation and extending over almost 150 million $\mathrm{km}^{2}$, about $30 \%$ of the earth's surface (Olson et al., 2001). Land surface features associated with terrestrial ecosystems vary greatly across the earth due 
to climate, soil and disturbance conditions. Some of these features, like leaf area index (LAI), surface roughness and albedo, exert a strong control on the exchange of biogeochemical fluxes, including carbon, water and nutrients, as well as energy fluxes between vegetation and the atmosphere (Bonan, 2008). These fluxes have an influence on multiple atmospheric processes that function over various temporal and spatial scales (Sellers et al., 1996). Because of the importance of land cover feedbacks on climate, a detailed and accurate description of global vegetation types and their patterns is thus a key component in dynamic global vegetation models (DGVMs) and earth system models (ESMs), with relevance for both weather and climate prediction. Presently, there are several global data sets of land cover available for modeling purposes, including MODIS-based land cover (Friedl et al., 2010), GLC2000 (Bartholome and Belward, 2005) and GLOBCOVER (Arino et al., 2008). However, the current generation of global land cover data sets provides little consistency in terms of time period of observations, spatial resolution, thematic resolution and accuracy standards. This presents various challenges for earth system modeling applications that require recent and consistent time series of land cover and particular thematic information regarding land cover categories (Giri et al., 2005; Herold et al., 2008; Neumann et al., 2007; Poulter et al., 2011; Wullschleger et al., 2014).

To address these challenges, the European Space Agency established the land cover component of the Climate Change Initiative (LC_CCI) and surveyed the land-surface modeling community to define user requirements for developing a new global land cover data set (Bontemps et al., 2012; Herold et al., 2011; Hollmann et al., 2013). The LC_CCI addressed these data needs by implementing an improved approach for mapping moderate-resolution global land cover consistently through time using surface reflectance from the MERIS and VEGETATION 1 and 2 sensors aboard ENVISAT and SPOT 4 and 5, respectively. The final LC_CCI product resulted in the development of three global land cover data sets, one for each of three epochs (1998-2002, 2003-2007 and 20082012) using a spectral classification approach derived from that of GLOBCOVER (Arino et al., 2008), yet with improved algorithms (Radoux et al., 2014). More importantly, its implementation to multi-year and multi-sensor time series ensured temporal consistency across epochs (Bontemps et al., 2012). The LC_CCI land cover maps depict the permanent features of the land surface by providing information on land cover classes defined by the United Nations Land Cover Classification System (UNLCCS). It also delivers land surface seasonality products in response to the needs of the ESM and DGVM communities for dynamic information about land-surface processes (Bontemps et al., 2012). Land surface seasonality products provide for each pixel the climatology describing, on a weekly basis, seasonal dynamics of snow cover, vegetation "greenness" based on the normalized difference vegetation index and burned area. Of par- ticular relevance to the needs of the ESM modeling community, the LC_CCI developed a framework to convert the categorical land cover classes to the fractional area of plant functional types, available at various spatial scales relevant to the respective ESMs.

Plant functional types, or PFTs, are a key feature of current generation ESMs and represent groupings of plant species that share similar structural, phenological, and physiological traits, and can be further distinguished by climate zone (Bonan et al., 2002). Typically, 5-15 PFTs are included in an earth system model simulation (Table 1), including natural and managed grasses with either $\mathrm{C} 3$ or $\mathrm{C} 4$ photosynthetic pathways, broadleaf or needleleaf trees with deciduous, evergreen or "raingreen" phenology, and shrubs (Alton, 2011; Krinner et al., 2005; Sitch et al., 2003). The PFT concept was originally proposed as a non-phylogenetic classification system partly not only to reduce computational complexity of ESMs but also to maintain a feasible framework for hypothesis testing. For example, interpreting the outcome of interactions for 5-15 PFTs following a model simulation is much more tractable than interpreting interactions among the thousands of plant species found throughout the world. The PFT concept also provides a practical solution to the problem that many of the plant traits required to parameterize a model at a species level are difficult to obtain (Ustin and Gamon, 2010). Second-generation DGVMs are currently addressing some of the limitations posed by the PFT concept as plant trait data become more widely available (Kattge et al., 2011), as model structure becomes more computationally efficient (Fisher et al., 2010), or as modeling concepts move toward adaptive trait rather than "fixed" values (Pavlick et al., 2013; Scheiter and Higgins, 2009).

This paper describes the LC_CCI land cover classification and presents a conversion scheme that "cross-walks" the categorical UNLCCS land cover classes to their PFT fractional equivalent. This work is one of several LC_CCI publications that have previously described the need for consistent land cover mapping (Bontemps et al., 2012), the user requirements (Tsendbazar et al., 2014) and the processing of remote sensing data (Radoux et al., 2014). Land cover to PFT conversion is a complex task and until the mapping of plant functional traits at global scale becomes possible (i.e., via "optical types"; Ustin and Gamon, 2010), the cross-walking approach remains a viable alternative for generating vegetation requirements for ESM and DGVM modeling approaches (Bonan et al., 2002; Faroux et al., 2013; Gotangco Castillo et al., 2013; Jung et al., 2006; Lawrence et al., 2011; Lawrence and Chase, 2007; Poulter et al., 2011; Verant et al., 2004; Wullschleger et al., 2014). The LC_CCI conversion scheme described here provides users with a transparent methodology as well as the flexibility to modify the cross-walking approach to fit the needs of their study region. The conversion scheme has been derived as part of a consultative process among experts involved in deriving the land cover map data and three ESM modeling groups as part of phase 1 of the 
Table 1. Plant functional types used by three earth system models and mapped by the LC_CCI Initiative.

\begin{tabular}{llll}
\hline ORCHIDEE & JSBACH & JULES & ESA LC_CCI \\
\hline Tropical broadleaf evergreen & Tropical broadleaf evergreen & Broadleaf trees & Broadleaf evergreen tree (BrEV) \\
Tropical broadleaf deciduous & Tropical broadleaf deciduous & Needleleaf trees & Broadleaf deciduous tree (BrDc) \\
Temperate needleleaf evergreen & Extratropical evergreen & C3 grass & Needleleaf evergreen tree (NeEv) \\
Temperate broadleaf deciduous & Extratropical deciduous & C4 grass & Needleleaf deciduous tree \\
Temperate broadleaf summer green & Rain-green shrubs & Shrubs & Broadleaf evergreen shrub \\
Boreal needleleaf evergreen & Deciduous shrubs & & Broadleaf deciduous shrub \\
Boreal broadleaf summer green & Tundra & Needleleaf evergreen shrub \\
Boreal needleleaf summer green & Swamp & & Needleleaf deciduous shrub \\
C3 grass & C3 grass & Natural grass (Nat. grass) \\
C4 grass & C4 grass & Managed grass (Man. grass) \\
C3 crops & C3 crops & \\
C4 crops & C4 crops & \\
\hline
\end{tabular}

project. With consensus for the thematic translation scheme, a conversion tool has been designed to spatially resample PFT fractions to various model grid formats common to the climate modeling community. The cross-walking table is expected to be periodically updated by the LC_CCI team; i.e., phase 2 of LC_CCI began in 2014, and will be revised to include modifications and improvements related to the classification scheme and mapping procedure.

\section{Methods}

\subsection{LC_CCI land cover mapping scheme}

The LC_CCI combined spectral data from $300 \mathrm{~m}$ full and $1000 \mathrm{~m}$ reduced resolution MERIS surface reflectance (and SPOT-VEGETATION for the pre-MERIS era) to classify land cover into 22 level 1 classes and 14 level 2 sub-classes following the UNLCCS legend (Di Gregorio and Jansen, 2000). The whole archive of full and reduced resolution MERIS data, 2003-2012, was first pre-processed in a series of steps that include radiometric and geometric corrections, cloud screening and atmospheric correction with aerosol retrieval before being merged to 7-day composites. An automated classification process, combining supervised and unsupervised algorithms, was then applied to the full time series to serve as a baseline to derive land cover maps that were representative of three 5 -year periods, referred to as epochs, for 2000 (1998-2002), 2005 (20032007) and 2010 (2008-2012). The classification process was achieved through back- and up-dating methods using the full-resolution SPOT-VEGETATION and MERIS time series. The three global land cover maps described all the terrestrial areas by 22 land cover classes explicitly defined by a set of classifiers according to the UNLCCS, each classifier referring to vegetation life form, leaf type and leaf longevity, flooding regime, non-vegetated cover types and artificiality. Inland open-water bodies and coastlines were mapped using wide-swath mode, image mode at medium-resolution
$(150 \mathrm{~m})$ and global monitoring image mode $(1 \mathrm{~km})$ acquired by the Advanced Synthetic Aperture Radar (ASAR) sensor aboard ENVISAT satellite for a single period (2005-2010).

In addition to the land cover classification, the land surface seasonality products describe, for $1 \mathrm{~km}^{2}$ rather than $300 \mathrm{~m}$ resolution, the average behavior and the inter-annual variability of the seasonal normalized difference vegetation index (NDVI), the burned area, and the snow occurrence, computed over the 1998-2012 period. These seasonality products were spatially coherent with the land cover classification and were provided at weekly intervals averaged over this 15-year period and were based on existing independent products: SPOT-VEGETATION NDVI daily time series, MODIS burned area (MCD64A1), and MODIS snow cover (MOD10A2). All products are provided to users in NetCDF and geotiff file format referenced to plate carrée projection using the World Geodetic System (WGS 84) and are available at http://maps.elie.ucl.ac.be/CCI/viewer/. Detailed descriptions of each component in the processing chain can be found on the European Space Agency Land Cover Climate Change Initiative website: http://www. esa-landcover-cci.org.

\subsection{Cross-walking land cover to PFTs}

The conversion of land cover classes to PFTs is a nontrivial task that is made more complicated by the fact that the number and description of PFTs are not standardized across DGVMs. In the past, land cover (and other) information has been used to derive PFT maps based on individual model PFT descriptions. The method used to convert the land cover to PFTs has not always been documented in detail for each model. The aim of the approach taken here was to develop a general framework that could easily be adapted to the specific PFT description of any individual model. In consultation with the three climate modeling teams engaged in the LC_CCI project, Laboratoire des Sciences du Climat et de l'Environnement (LSCE), Met Office Hadley 


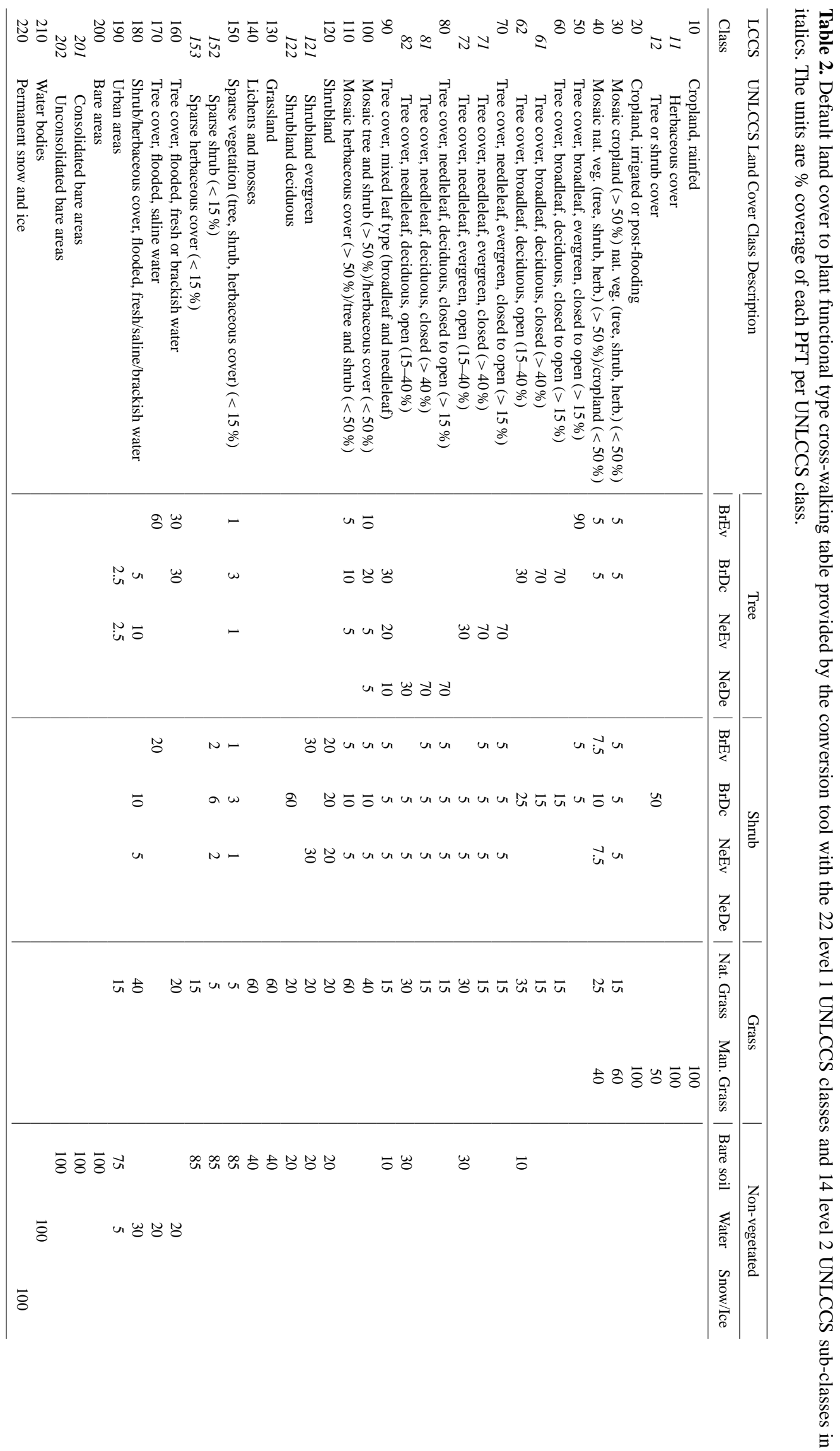


Centre (MOHC) and Max Planck Institute for Meteorology (MPI), 10 PFT groups were defined based on their phenology (needleleaf or broadleaf, evergreen or deciduous), physiognomy (tree, shrub, or grass) and grassland management status (natural or managed). Three additional non-PFT classes were added for bare soil, water and snow/ice. The cross-walking methodology is based on the approach of Poulter et al. (2011) and assumes that each UNLCCS category could be split into one or more PFT classes according to the LC class description at the per pixel level (Table 2). For example, the "cropland" UNLCCS land cover class was assigned as $100 \%$ managed grass, whereas the UNLCCS "tree cover, needleleaf evergreen, open (15-30\%)" class was assigned to $30 \%$ needleleaf evergreen, $5 \%$ broadleaf deciduous shrub, $5 \%$ needleleaf evergreen shrub and $15 \%$ natural grass. Of note, wet tropical forest vegetation, mainly the UNLCCS class "tree cover, broadleaf evergreen, closed to open (>15\%)", was assigned to the PFT categories of "broadleaf evergreen" tree $(90 \%)$ and deciduous (5\%), evergreen shrub (5\%) following observations that moist tropical forests tend to have indeterminate phenology rather than distinct periods of onset and offset (Borchert et al., 2002; Fontes et al., 1995; Reich and Borchert, 1984). The derivation of Table 2 was the result of consultative process among the producers of the land cover map and the three modeling groups that reached a consensus on the PFT fractions for each LCCS-defined land cover class. The aim of this process was to gain a fuller understanding of the methods behind, and implications of, the respective vegetation classifications (LC and PFT). For example, previous LC class descriptions have included "semi-deciduous" in the description of broadleaf evergreen trees, as in tropical rainforests in particular, phenological strategies of certain species result in more pronounced seasonal leaf dynamics. However, such subtle differences in functionality are not currently incorporated into DGVMs, and tropical rainforests are considered to be $100 \%$ evergreen. Thus, in the crosswalking table derived in this study, the relevant LC class was mapped only as evergreen trees and shrubs (see LC class 50 in Table 2). Other issues that were discussed included how different vegetation types are treated within a grid cell for DGVMs and the lack of representation of over- and understory canopies, which both had implications for how to deal with mosaic and open-cover classes.

For the most part, the cross-walking approach followed the definitions of the UNLCCS classes, where fixed proportions of land cover were split using a one-to-one rule for the respective PFT categories, as described above. In cases where the UNLCCS class was defined by a large range of tree cover and with no upper bound, i.e., "> $15 \%$ " (Table 2), the uncertainties in this conversion can be considered larger than compared with other categories. In these cases, the land cover remote sensing team of experts provided the criteria for the conversion approach, taking into account their improved understanding of the constraints of DGVMs. The impact of these uncertainties on the final PFT fractions, and on the sim- ulated variables, is beyond the scope of this study. Here we purely aim to properly document a new, generic method for mapping between LC classes and PFT fractions that can be used for all DGVMs. However, the issue of uncertainty in the cross-walking procedure is currently being investigated in phase 2 of the LC_CCI project.

\subsection{The LC_CCI conversion tool}

The LC_CCI land cover and seasonality products are initially downloaded in full spatial resolution, i.e., $300 \mathrm{~m}$ grid cells for land cover, and $1 \mathrm{~km}$ grid cells for the seasonality products, at global extent in plate carrée projection. In order to fulfill a range of ESM requirements, the LC_CCI project team developed the LC_CCI user tool to allow users to adjust parameters of the LC products in a way that is suitable to their model setup, including modifying the spatial resolution and converting the LC_CCI classes to fractional PFT area. The BEAM Earth Observation Toolbox and Development Platform, designed for visualization and analysis of ENVISAT products, was selected to provide the basis of the conversion software. A list of resampling resolution and coordinate system options is provided in Table 3 . The coordinate re-projection and aggregation of the LC_CCI data uses slightly different resampling algorithms depending on whether the tool is used on the land cover or seasonality products. The tool converts the original LC_CCI geotiff file to target files produced in NetCDF-4 format and following CF (Climate and Forecast) conventions, more commonly used in numerical modeling. The open-source BEAM tool (source code at https://github.com/bcdev) can be run independently using either Windows or Unix-based operating systems and the compiled operational tool can be downloaded from http: //maps.elie.ucl.ac.be/CCI/viewer/download.php.

\subsection{Re-sampling algorithm for LC_CCI land cover}

For the land cover classes, the resampling algorithm produces an aggregated LC_CCI data set that in addition to the fractional area of each PFT, also includes the fractional area of each LC_CCI UNLCCS class, the majority (dominant) LC_CCI UNLCCS class and the overall accuracy of the aggregated classification. The majority class $n$ is defined as the LC_CCI class which has the rank $n$ for the sorted list of LC_CCI classes by fractional area in the target cell (see Fig. 1). The number of majority classes computed is a parameter, which can be defined by the user, so that the full number of LCCS classes can be reduced to a user-defined subset, i.e., the top 3. Each original valid land, water, snow or ice pixel contributes to the final target cell according to its area percentage contribution. The accuracy is calculated by the median of the land cover classification probability values weighted by the fractional area. 
Table 3. Minimum set of projections and spatial resolutions included in the re-projection, aggregation, subset and conversion tool developed by the LC_CCI project - LC_CCI user tool.

\begin{tabular}{ll}
\hline Regional subset ID & Predefined regional subset \\
\hline Spatial resolution & Free specification of regional subset (four corner coordinates) \\
& Original resolution \\
& $0.25^{\circ}$ \\
& $0.5^{\circ}$ \\
& $1^{\circ}$ \\
& $1.875^{\circ}$ \\
& $1.875 \times 1.25^{\circ}$ \\
& $3.75 \times 2.5^{\circ}$ \\
\hline Projection & Original projection (plate carrée) \\
& Gaussian grid, \\
& Rotated lat/long grid \\
\hline Conversion of LC_CCI classes to PFT & LC_CCI standard cross table \\
& User-defined cross table \\
\hline
\end{tabular}

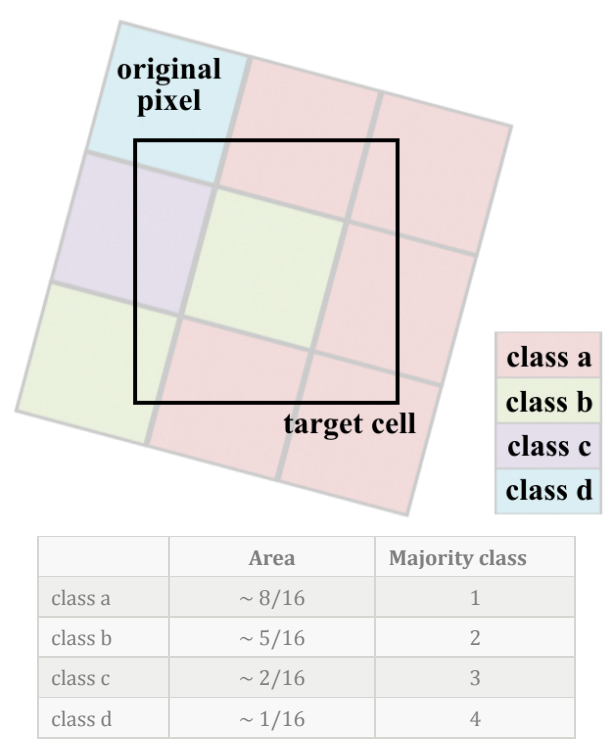

Figure 1. Visualization of the pixel aggregation from the spatial resolution of original LC_CCI map product into the user-defined spatial resolution of the aggregated LC_CCI map product.

\subsection{Re-sampling algorithm for LC_CCI seasonality products}

The aggregation of LC_CCI seasonality products is specific for NDVI (i.e., greenness), burned areas and snow cover. In the case of the LC_CCI NDVI condition, the mean NDVI over all valid NDVI observations is included in the aggregated product. The burned area and snow cover LC_CCI products also contain three different layers: the proportion of area (in \%) covered by burned or snow area, the average frequency of the burned area or snow area detected over the aggregated zone and the sum of all valid observations of burned or snow area. Similar to aggregation rules for land cover, each original pixel contributes to the target cell according to its area percentage, but the value of a pixel will only be considered if its value falls within its valid range, i.e., zero to one for NDVI.

\subsection{Extension to specific model needs}

The LC_CCI tool provides users with a zero-order classification; that is, the PFT classes are defined as broadly as possible so that users have the advantage to continue to aggregate to the requirements of their model (Fig. 2). For example, models that do not include shrub PFTs can merge shrub and tree categories together to create a single woody PFT category. Modeling groups that require climatic distinctions for PFTs; for example, temperate versus tropical versus boreal types can use their own climate or biome data sets, such as Köppen-Geiger or Trewartha ecological zones (Baker et al., 2010; Kottek et al., 2006; Peel et al., 2007), and define classification rules based on temperature thresholds, for example (Poulter et al., 2011). Most models also require a distinction between the $\mathrm{C} 3$ and $\mathrm{C} 4$ photosynthetic pathways for different grass species, where $\mathrm{C} 4$ is more common in warm and dry climates (Edwards et al., 2010; Still et al., 2003). The photosynthetic biochemistry of $\mathrm{C} 4$ grasses is very different to $\mathrm{C} 3$ grasses and their distribution can be mapped either according to climate (Poulter et al., 2011) or to some combination of remote sensing, ground-based observations and ecosystem modeling (Still et al., 2003). The LC_CCI managed grassland PFT category represents all non-irrigated, irrigated and pasture lands, and therefore drawing finer thematic distinctions between these must come from country or sub-country statistics similar to downscaling work made by Hurtt et al. (2006), Klein Goldewijck and Batjes (1997) and others (Monfreda et al., 2008; Ramankutty and Foley, 1998). 


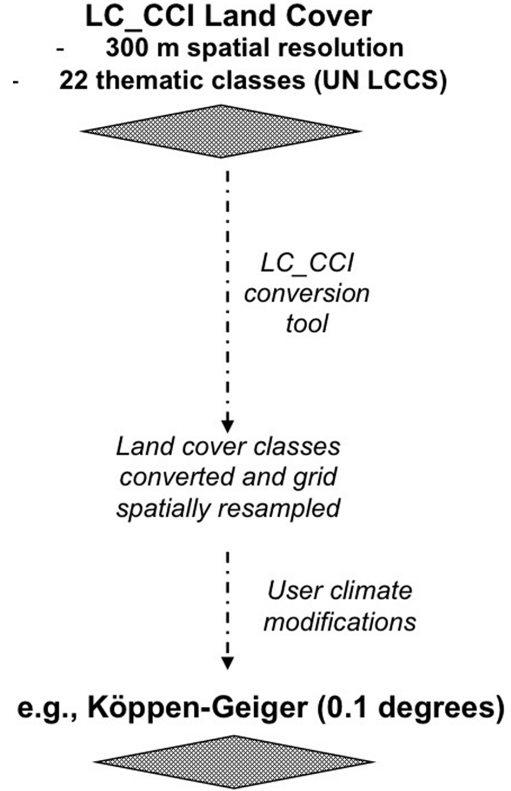

Figure 2. The LC_CCI land cover conversion tool processing chain requires converting the thematic legend and resampling the grid resolution to user defined PFT and coordinate system. Independent of the LC_CCI tool, users can append climate classes to the PFT aggregation.

\subsection{Analysis and comparison to PFT maps}

For analysis and demonstration of the tool, we compare the LC_CCI PFTs with the original PFTs used by the land surface model (LSM) components of the ESMs from the three modeling centers developing ORCHIDEE at LSCE (Krinner et al., 2005), JULES at MOHC (Clark et al., 2011; Cox et al., 2000; Pacifico et al., 2011), and JSBACH at MPI (Knorr, 2000; Pongratz et al., 2009; Reick et al., 2013). The original ORCHIDEE PFT map, based on 12 PFTs plus bare soil, has its origins in the Olson land cover data set from the 1980s (Olson et al., 1983) and the International Geosphere Biosphere Program (IGBP) DISCover data set for the period 1992-1993 (Loveland and Belward, 1997). This was implemented within ORCHIDEE using a look-up table approach to estimate PFT fractions (Verant et al., 2004). The JULES model also uses PFT distributions derived from the IGBP DISCover data set to estimate fractional coverage of five PFTs and four non-vegetated surfaces (water, urban, snow/ice and bare soil). JSBACH uses original data from Wilson and Henderson-Sellers (1985) and continuous tree fractions from DeFries et al. (1999) to represent the distribution and abundance of 12 PFTs. The LC_CCI Epoch 2010 was converted to 0.5 degree resolution using the LC_CCI user tool and compared with the individual default model PFT maps to illustrate regional differences and biases between products and to provide a baseline of how the LC_CCI products may improve LSM performance.

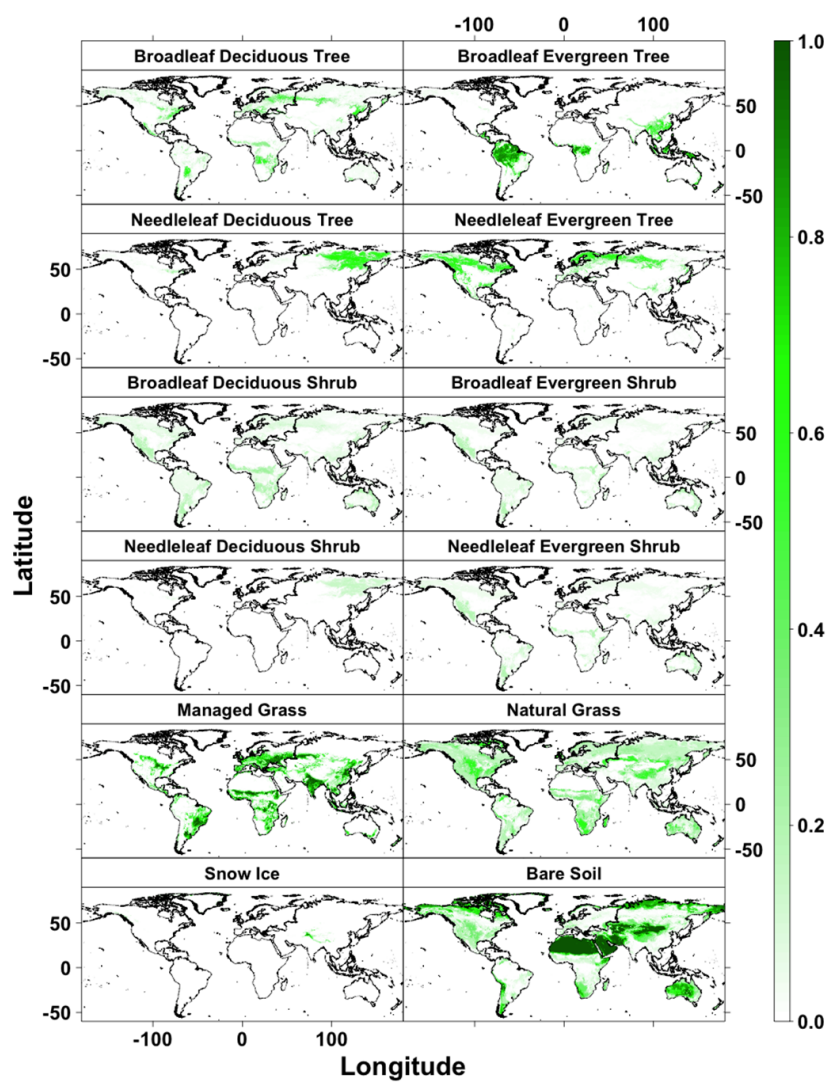

Figure 3. Fractional coverage of plant functional types, at $0.5^{\circ}$ spatial resolution, calculated from original $300 \mathrm{~m}$ LC_CCI data set, epoch 2008-2012, using the LC_CCI conversion tool.

\section{Results}

\subsection{Global summary of LC_CCI}

The global land areas covered by the aggregated $0.5^{\circ}$ LC_CCI PFT equivalents (Fig. 3) are dominated by barren and bare soil $\left(39 \mathrm{Mkm}^{2}\right)$, followed by forests $\left(30 \mathrm{Mkm}^{2}\right)$, managed grasslands, croplands and pasture $\left(25 \mathrm{Mkm}^{2}\right)$, natural grasslands $\left(18 \mathrm{Mkm}^{2}\right)$, and shrublands $\left(14 \mathrm{Mkm}^{2}\right)$. For comparison, the MODIS collection 5 land cover product developed by Friedl et al. (2010) covers barren area $18 \mathrm{Mkm}^{2}$, forest and savanna at $49 \mathrm{Mkm}^{2}$, a shrubland area of $22 \mathrm{Mkm}^{2}$, and $12 \mathrm{Mkm}^{2}$ for croplands. With reference to the Food and Agriculture Organization (FAO) statistics, forest area is reported as $38 \mathrm{Mkm}^{2}$ (FAO and JRC, 2012), cropland area as approximately $15 \mathrm{Mkm}^{2}$ (Monfreda et al., 2008) and pasture lands of $28 \mathrm{Mkm}^{2}$ (Ramankutty et al., 2008). While part of the areal differences are explained by the spatial resolution between the moderate-resolution MODIS data $(500 \mathrm{~m})$ in comparison to the $0.5^{\circ}$ LC_CCI data, thematic differences introducing uncertainty in aggregating to forest, grassland, classes and factors stemming from different definitions of forest cover thresholds are used to categorize for- 


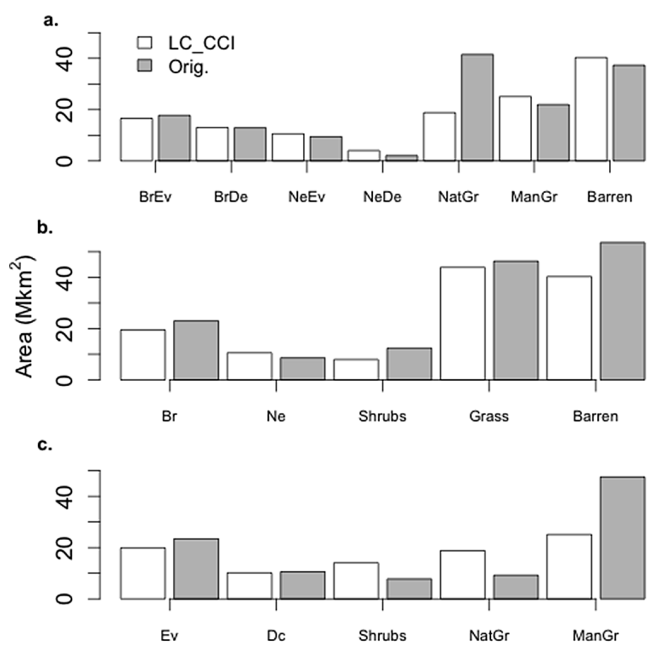

Figure 4. Global PFT coverage comparing the LC_CCI and original data sets for (a) ORCHIDEE, (b) JULES and (c) JSBACH. Where "Br" is broadleaf, "Ne" is needleleaf, "Ev" is evergreen, "De" is deciduous, "ManGr" is managed grassland, "NatGr" is natural grassland and "barren" includes bare soil or ice. Note JSBACH has no bare soil category.

est land between the UNLCCS approach (10\% cover) and the IGBP $(60 \%)$ approach used for MODIS. In addition, the UNLCCS to PFT conversion approach considers assumptions related to plant community level variability, and so a bare soil fraction is introduced during the conversion (see Table 3) increasing its global area and partially explaining the difference with MODIS land cover.

\subsection{Comparison with original PFT maps}

Differences between the LC_CCI PFT data sets and the original PFT data sets were specific for each ESM (Fig. 4) largely because the original reference data were different per modeling group. Another challenge was that different PFT classification schemes were used for each model (Table 1), introducing further aggregation uncertainties in the comparison between LC_CCI and the original PFT data.

For all modeling teams, grassland PFT distributions showed the largest changes, with significant reductions in northern latitudes for ORCHIDEE and JULES (Fig. 6). For ORCHIDEE, the grassland PFT reductions were associated with an increase in bare soil, together with a shift from $\mathrm{C} 3$ grasses to (boreal) forest in the mid-to-high latitudes (Fig. 5). Agricultural PFTs, not included in JULES, were similar for the original ORCHIDEE and LC_CCI inputs at regional scales, but showed increases in tropical regions where deforestation activities were high, e.g., the Brazilian arc of deforestation region. JSBACH generally had a reduction in cropland area, especially over North America and the North African arid regions.

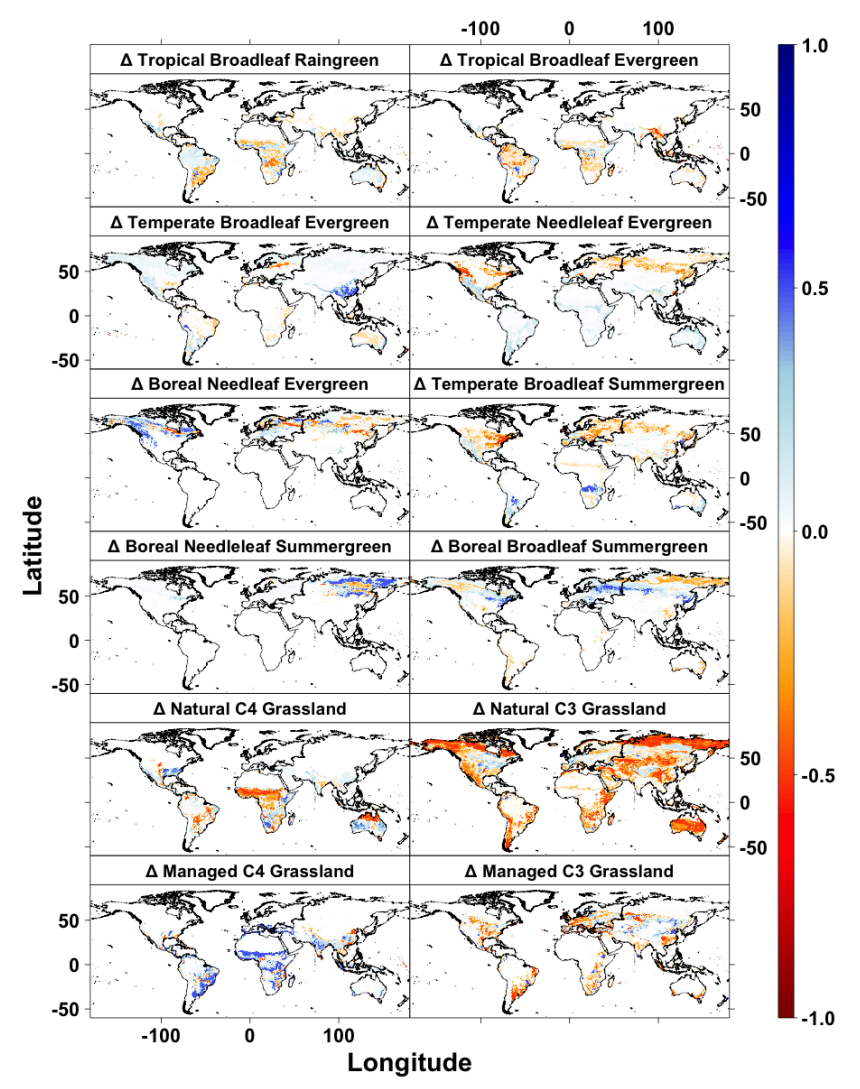

Figure 5. Difference in fractional coverage between the LC_CCI (epoch 2008-2012) and original ORCHIDEE PFT data set, based on Olson et al. (1983).

Over arid regions, in comparison to the original PFT map, JULES decreased in C4 grasses over Australia, with an associated increase in the fractional cover of shrubs and bare soil. In the Sahel, apparent differences in the definition of natural and managed $\mathrm{C} 4$ grass account for differences found between ORCHIDEE and JSBACH. The inclusion of the LC_CCI product resulted in a large increase in the $\mathrm{C} 4$ grass fraction over the Sahel in ORCHIDEE, whereas no significant change in the $\mathrm{C} 4$ grass fraction has been found over these areas for JSBACH. Instead, an increase in C4 crops was found over the Sahel for JSBACH. Since the JSBACH conversion also accounts for pasture, this difference may be well the result of the pasture definition, which is a weighted part of all herbaceous PFTs. This also partly explains why the JSBACH C4 pasture PFT decreases exactly in the same areas where the $\mathrm{C} 4$ crops increase due to the use of the LC_CCI data. In JULES, the $\mathrm{C} 4$ types over Sahel shift to bare soil.

In the tropics, reductions in broadleaf tropical tree cover were largely consistent across all three ESMs, although increases in broadleaf forest area were found for some parts of the African Congo Basin for JULES (Fig. 6). Needleleaf forest area increased compared to the reference data set for both JULES and JSBACH for boreal Europe and Australia (shrub- 

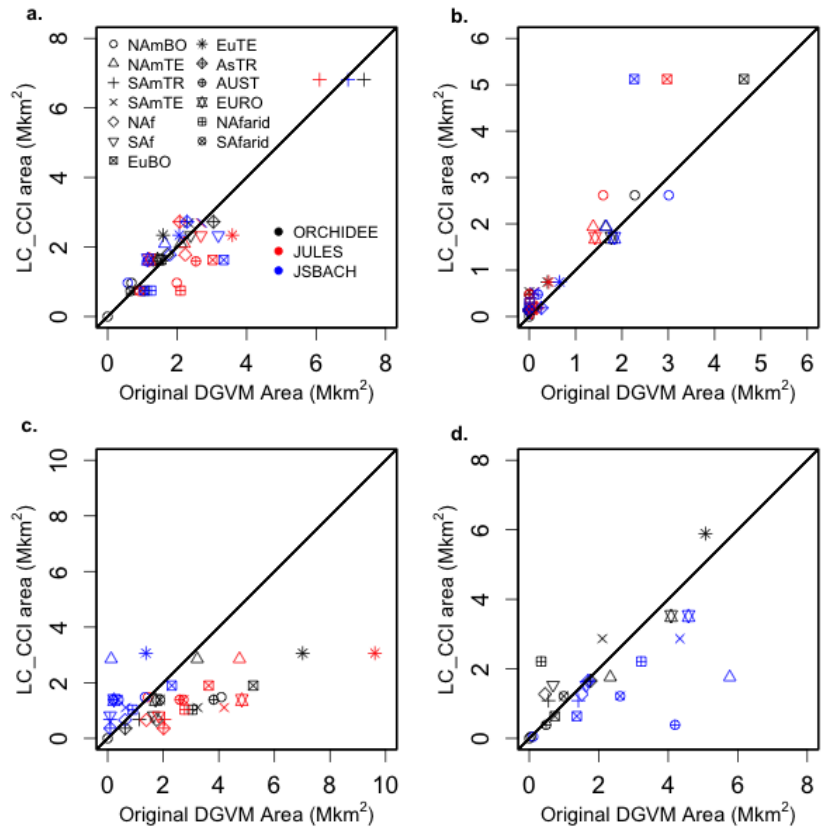

Figure 6. Regional correlations between the original ESM PFT coverage and the LC_CCI, epoch 2008-2012, coverage for (a) broadleaf trees, (b) needleleaf trees, (c) natural grasslands and (d) managed grasslands. The regions follow the TRANSCOM experiment biome boundary definitions, which partition terrestrial ecosystems into 13 regions of similar vegetation (see Appendix A).

land PFTs). The increase in needleleaf PFTs in boreal Europe was partially associated with a decrease in broadleaves (Fig. 6a and b) for all three models, but also a decrease in natural grassland cover.

\section{Discussion}

\subsection{Advantages of the LC_CCI for ESM modeling}

The LC_CCI approach provides the ESM modeling community with a flexible tool for using up-to-date land cover information consistently provided over time. Following the requests of the user survey, the land cover data set is available across multiple spatial domains, conforms to standard file formats used in numerical models, and includes information on classification confidence levels for the land cover classes and resulting PFT fractions. The standardized conversion tool provides users with a consistent documented approach for aggregating land cover classes and thus overcomes limitations associated with consensus approaches (e.g., Tuanmu and Jetz 2014). Of particular importance is that the multitemporal LC_CCI mapping approach facilitated more accurate mapping leading to improved remote sensing observations of deforested areas in the tropics, the tree line-tundra boundary in the high latitudes, and better distinctions between managed and non-managed grasslands in Africa. Ad- ditionally, the ASAR-based water bodies and coastline delineation helped to standardize the physical boundaries between terrestrial and water systems for all models. Using this standardized PFT mapping approach for ESMs can be expected to reduce model ensemble uncertainty as attempted by recent inter-model comparison efforts (Huntzinger et al., 2013).

\subsection{Opportunities for phase 2}

During phase 1 of the LC_CCI project (2011-2014) several limitations of the conversion scheme and tool were recognized and have been targeted for improvement in phase 2, where improvements to the land cover thematic classes and to the conversion scheme will be made. For example, in the high latitudes, a reduction in grassland fractional cover was observed with the LC_CCI product for all models, and on further investigation, it was recognized that a better representation of lichens and moss vegetation (Class 140, Table 3) would be an improvement for the sparse vegetation category (Class 150), especially in the high latitudes. Conversion of high-latitude land cover classes to PFT equivalents has been a challenge in several recent regional studies (Ottlé et al., 2013; Wullschleger et al., 2014) where discriminating spectrally between shrubs and trees, or grass and non-vascular plant species, remains difficult. Accurate mapping of high-latitude vegetation can be particularly important for modeling wildfires (Yue et al., 2014), where the spread of tundra fire is sensitive to fuel loading. In the tropics, the seasonal cycle of forest canopies continues to be a contentious issue (Morton et al., 2014; Myneni et al., 2007; Poulter and Cramer, 2009; Ryan et al., 2014) with the binary distinction between evergreen and deciduous phenology proving to be overly simplistic where semi-deciduous traits are perhaps more appropriate (Borchert et al., 2002), and thus the development of tropical phenology traits that correspond to recent observations is a high priority (Bi et al., 2015). More specifically, phase 2 will (i) target improved thematic accuracy with a specific focus on transition areas (e.g., grassland-sparse vegetation-bare soil, tree-shrub-grassland) and the distinction between $\mathrm{C} 3$ and $\mathrm{C} 4$ grasses, (ii) create a historical land cover time series to cover the 1990s using $1 \mathrm{~km}$ Advanced Very High Resolution Radiometer (AVHRR) NDVI surface reflectances, (iii) include more detailed change detection, with more classes, i.e., IPCC land categories (forests, agriculture, grassland, settlement, wetland, other land) as targets, and (iv) deliver an albedo and/or LAI seasonality product.

Physiological traits such as nitrogen fixation and different photosynthetic pathways, C3, C4 or crassulacean acid metabolism (CAM) are presently not detectable from surface reflectance values, and so broad climate-based assumptions must be made to split into these groups. These assumptions can lead to large uncertainties that can impact a chain of ecosystem processes and land surface properties. While the LC_CCI data set provides updated information on inland water bodies, the seasonality of water bodies and wet- 
lands is yet to be represented and only considered in radarbased surveys (Schroeder et al., 2015). Finally, the existing 22 UNLCCS land cover classes currently do not include pastures, whereas the importance of grazing on biogeochemical cycling is becoming increasingly recognized (Foley et al., 2005). Instead, pastures are currently mapped as croplands or grasslands according to their degree of management. Better thematic discrimination between these three classes would clearly improve the carbon cycle modeling as agriculture, in the broadest sense, is a significant contributor to land degradation and anthropogenic global greenhouse gas emissions (Haberl et al., 2007). Earth observation products are generally limited to mapping land surface structural properties rather than functional properties, and model-data fusion approaches can help reconcile problems that might arise from this limitation, especially in the case of grassland systems which may be managed or unmanaged, or may have different photosynthetic pathways. Nevertheless, remote sensing of land "management" categories remains a challenging task since existing classification approaches have yet to demonstrate an ability to capture the whole range of rangelands and crop diversity at global scale.

\subsection{Earth system modeling challenges}

Updating PFT data sets used in ESMs will clearly lead to improvements in the realism of the patterns of biogeography and have important feedbacks on simulating ecosystem processes and interactions with the atmosphere. Available PFT data sets used in ESMs remain outdated, using land cover information from the 1980s mainly because of a lack of tools available for cross-walking land cover to PFTs. The LC_CCI scheme and tool fills a critical data need for improving the representation of carbon, water and energy cycles be- ing developed by the modeling community; however, extensive model benchmarking and calibration activities may now be necessary before the new PFT data sets result in model improvement. For example, model processes may be calibrated to some extent to produce performance metrics under outdated land cover information, and thus a range of benchmarks should be considered when transitioning to new PFT information.

\section{Summary}

The LC_CCI has made significant progress in responding to the ESM community data needs (Tsendbazar et al., 2014). These include

- new land cover classifications for three Epochs using consistent algorithms and based on the UNLCCS system;

- a user-friendly tool for mapping the UNLCCS classes into user-defined PFT classes and at most grid resolutions used by the ESM community;

- seasonality products describing average weekly conditions for burned area, NDVI and snow cover;

- confidence information for each of the UNLCCS classes and a median estimate for the converted PFT legend.

The UNLCCS-PFT conversion tool and the land cover products will continue to be improved during phase 2 of the LC_CCI with updates made periodically and described at http://www.esa-landcover-cci.org. 


\section{Appendix A}

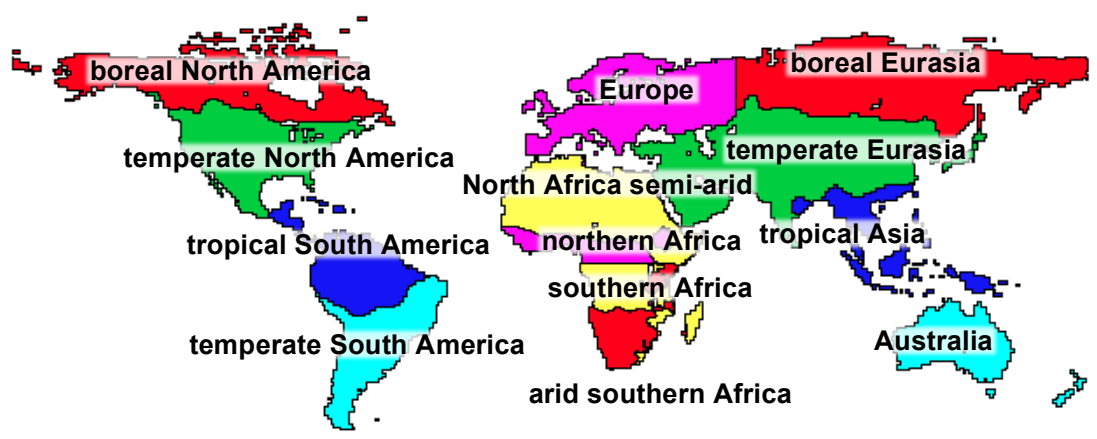

Figure A1. TRANSCOM experiment biome boundaries from Gurney et al. (2002). The codes from Fig. 6 are boreal North America (NAmBO), temperate North America (NAmTE), tropical South America (SAmTR), temperate South America (SAmTE), northern Africa (NAf), southern Africa (SAf), boreal Eurasia (EuBO), temperate Eurasia (EuTE), tropical Asia (AsTR), Australia (AUST), Europe (EURO), arid North Africa (NAfarid), arid southern Africa (SAfarid). 
Acknowledgements. The LC_CCI project was funded by the European Space Agency Climate Change Initiative phase 1. The authors appreciate the support and comments from Frank Martin Seifert, Vasileos Kalogirou and Fabrizio Ramoino.

Edited by: A. Archibald

\section{References}

Alton, P. B.: How useful are plant functional types in global simulations of the carbon, water, and energy cycles?, J. Geophys. Res., 116, G01030, doi:10.1029/2010JG001430, 2011.

Arino, O., Bicheron, P., Achard, F., Latham, J., Witt, R., and Weber, J. L.: GLOBCOVER The most detailed portrait of Earth, ESA Bull.-Eur. Space, 136, 24-31, 2008.

Baker, B., Diaz, H., Hargrove, W., and Hoffman, F. M.: Use of the Köppen-Trewartha climate classification to evaluate climatic refugia in statistically derived ecoregions for the People's Republic of China, Climatic Change, 98, 113-131, 2010.

Bartholome, E. and Belward, A. S.: GLC2000: a new approach to global land cover mapping from Earth observation data, Int. J. Remote Sens., 26, 1959-1977, 2005.

Bi, J., Knyazikhin, Y., Choi, S., Park, T., Barichivich, J., Ciais, P., Fu, R., Ganguly, S., Hall, F., Hilker, T., Huete, A., Jones, M., Kimball, J., Lyapustin, A. I., Mõttus, M., Nemani, R. R., Piao, S., Poulter, B., Saleska, S. R., Saatchi, S. S., Xu, L., Zhou, L., and Myneni, R. B.: Sunlight mediated seasonality in canopy structure and photosynthetic activity of Amazonian rainforests, Environ. Res. Lett., 10, 064014, doi:10.1088/17489326/10/6/064014, 2015.

Bonan, G. B.: Forests and climate change: Forcings, feedbacks, and the climate benefits of forests, Science, 320, 1444-1449, 2008.

Bonan, G. B., Levis, S., Kergoat, L., and Oleson, K. W.: Landscapes as patches of plant functional types: An integrating concept for climate and ecosystem models, Global Biogeochem. Cy., 16, 5.21-25.23, 2002.

Bontemps, S., Herold, M., Kooistra, L., van Groenestijn, A., Hartley, A., Arino, O., Moreau, I., and Defourny, P.: Revisiting land cover observation to address the needs of the climate modeling community, Biogeosciences, 9, 2145-2157, doi:10.5194/bg9-2145-2012, 2012.

Borchert, R., Rivera, G., and Hagnauer, W.: Modification of vegetative phenology in a tropical semideciduous forest by abnormal drought and rain, Biotropica, 34, 381-393, 2002.

Clark, J. S., Bell, D. M., and Hersh, M.: Climate change vulnerability of forest biodiversity: climate and competition tracking of demographic rates, Global Change Biol., 17, 1834-1849, 2011.

Cox, P. M., Betts, R. A., Jones, C. D., Spall, S. A., and Totterdell, I. J.: Acceleration of global warming due to carbon-cycle feedbacks in a coupled climate model, Nature, 408, 184-187, 2000.

DeFries, R., Townshend, J. R. G., and Hansen, M. C.: Continuous fields of vegetation characteristics at the global scale at $1-\mathrm{km}$ resolution, J. Geophys. Res., 104, 911-916, 1999.

Di Gregorio, A. and Jansen, L.: Land Cover Classification System (LCCS): Classification Concepts And User Manual, Rome, Italy, 2000.

Edwards, E. J., Osborne, C. P., Stromberg, C. A. E., Smith, S. A., and Consortium, C. G.: The Origins of C4 Grasslands: Integrat- ing Evolutionary and Ecosystem Science, Science, 328, 587591, 2010.

FAO and JRC: Global forest land-use change 1990-2005, Food and Agriculture Organization of the United Nations and European Commission Joint Research Centre, Rome, FAO, 2012.

Faroux, S., Kaptué Tchuenté, A. T., Roujean, J.-L., Masson, V., Martin, E., and Le Moigne, P.: ECOCLIMAP-II/Europe: a twofold database of ecosystems and surface parameters at $1 \mathrm{~km}$ resolution based on satellite information for use in land surface, meteorological and climate models, Geosci. Model Dev., 6, 563582, doi:10.5194/gmd-6-563-2013, 2013.

Fisher, R. A., McDowell, N., Purves, D., Moorcroft, P., Sitch, S., Cox, P. M., Huntingford, C., Meir, P., and Woodward, F. I.: Assessing uncertainties in a second-generation dynamic vegetation model caused by ecological scale limitations, New Phytol., 187, 666-681, 2010.

Foley, J. A., Defries, R., Asner, G. P., Barford, C., Bonon, G., Carpenter, S. R., Chapin, F. S., Coe, M. T., Daily, G. C., Gibbs, H. K., Helkowski, J. H., Holloway, T., Howard, E. A., Kucharik, C. J., Monfreda, C., Patz, J. A., Prentice, I. C., Ramankutty, N., and Snyder, P. K.: Global consequences of land use, Science, 309, 570-574, 2005.

Fontes, J., Gastellu-Etchegorry, J. P., Amram, O., and Fluzat, G.: A Global Phenological Model of the African Continent, Ambio, 24, 297-303, 1995.

Friedl, M. A., Sulla-Menashe, D., Tan, B., Schneider, A., Ramankutty, N., Sibley, A., and Huang, X.: MODIS Collection 5 Global Land Cover: Algorithm refinements and characterization of new datasets, Remote Sens. Environ., 114, 168-182, 2010.

Giri, C., Zhu, Z., and Reed, B.: A comparative analysis of the Global Land Cover 2000 and MODIS land cover data sets, Remote Sens. Environ., 94, 123-132, 2005.

Gotangco Castillo, C. K., Levis, S., and Thornton, P.: Evaluation of the New CNDV Option of the Community Land Model: Effects of Dynamic Vegetation and Interactive Nitrogen on CLM4 Means and Variability*, J. Climate, 25, 3702-3714, 2013.

Gurney, K. R., Law, R. M., Denning, A. S., Rayner, P., Baker, D., Bousquet, P., Bruhwiler, L., Chen, Y. H., Ciais, P., Fan, S. M., Fung, I. Y., Gloor, M., Heimann, M., Higuchi, N., John, J., Maki, T., Maksyutov, S., Masarie, K., Peylin, P., Prather, M., Pak, B. C., Randerson, J. T., Sarmiento, J., Taguchi, S., Takahashi, T., and Yuen, C. W.: Towards robust regional estimates of $\mathrm{CO}_{2}$ sources and sinks using atmospheric transport models, Nature, 415, 626630, 2002.

Haberl, H., Erb, K. H., Krausmann, F., Gaube, V., Bondeau, A., Plutzar, C., Gingrich, S., Lucht, W., and Fischer-Kowalski, M.: Quantifying and mapping the human appropriation of net primary production in earth's terrestrial ecosystems, P. Natl. Acad. Sci., 104, 12942-12947, 2007.

Herold, M., Mayaux, P., Woodcock, C. E., Baccini, A., and Schmullius, C.: Some challenges in global land cover mapping: An assessment of agreement and accuracy in existing $1 \mathrm{~km}$ datasets, Remote Sens. Environ., 112, 2538-2556, 2008.

Herold, M., van Groenestijn, A., Kooistra, L., Kalogirou, V., and Arino, O.: User Requirements documents: Land Cover CCI, Université catholique de Louvain (UCL)-Geomatics, Louvain-laNeuve, Belgium., 2011.

Hollmann, R., Merchant, C., Saunders, R., Downy, C., Buchwitz, M., Cazenave, A., Chuvieco, E., Defourny, P., de Leeuw, G., 
Forsberg, R., Holzer-Popp, T., Paul, F., Sandven, S., Sathyendranath, S., van Roozendael, M., and Wagner, W.: The ESA climate change initiative: Satellite data records for essential climate variables, B. Am. Meteorol. Soc., 94, 1541-1552, 2013.

Huntzinger, D. N., Schwalm, C., Michalak, A. M., Schaefer, K., King, A. W., Wei, Y., Jacobson, A., Liu, S., Cook, R. B., Post, W. M., Berthier, G., Hayes, D., Huang, M., Ito, A., Lei, H., Lu, C., Mao, J., Peng, C. H., Peng, S., Poulter, B., Riccuito, D., Shi, X., Tian, H., Wang, W., Zeng, N., Zhao, F., and Zhu, Q.: The North American Carbon Program Multi-Scale Synthesis and Terrestrial Model Intercomparison Project - Part 1: Overview and experimental design, Geosci. Model Dev., 6, 2121-2133, doi:10.5194/gmd-6-2121-2013, 2013.

Hurtt, G. C., Frolking, S., Fearon, M. G., Moore, B., Shevliakova, E., Malyshev, S., Pacala, S., and Houghton, R. A.: The underpinnings of land-use history: three centuries of global gridded landuse transitions, wood-harvest activity, and resulting secondary lands, Glob. Change Biol., 12, 1208-1229, 2006.

Jung, M., Henkel, K., Herold, M., and Churkina, G.: Exploiting synergies of global land cover products for carbon cycle modeling, Remote Sens. Environ., 101, 534-553, 2006.

Kattge, J., Diaz, S., Lavorel, S., Prentice, I. C., Leadley, P., Bönisch, G., Garnier, E., Westoby, M., Reich, P. B., Wright, I. J., Cornelissen, J. H. C., Violle, C., Harrison, S. P., Van Bodegom, P. M., Reichstein, M., Enquist, B. J., Soudzilovskaia, N. A., Ackerly, D. D., Anand, M., Atkin, O., Bahn, M., Baker, T. R., Baldocchi, D., Bekker, R., Blanco, C. C., Blonder, B., Bond, W. J., Bradstock, R., Bunker, D. E., Casanoves, F., Cavender-Bares, J., Chambers, J. Q., Chapin III, F. S., Chave, J., Coomes, D., Cornwell, W. K., Craine, J. M., Dobrin, B. H., Duarte, L., Durka, W., Elser, J., Esser, G., Estiarte, M., Fagan, W. F., Fang, J., FernándezMéndez, F., Fidelis, A., Finegan, B., Flores, O., Ford, H., Frank, D., Freschet, G. T., Fyllas, N. M., Gallagher, R. V., Green, W. A., Gutierrez, A. G., Hickler, T., Higgins, S. I., Hodgson, J. G., Jalili, A., Jansen, S., Joly, C. A., Kerkhoff, A. J., Kirkup, D., Kitajima, K., Kleyer, M., Klotz, S., Knops, J. M. H., Kramer, K., Kühn, I., Kurokawa, H., Laughlin, D., Lee, T. D., Leishman, M., Lens, F., Lenz, T., Lewis, S. L., Lloyd, J., Llusià, J., Louault, F., Ma, S., Mahecha, M. D., Manning, P., Massad, T., Medlyn, B. E., Messier, J., Moles, A. T., Müller, S. C., Nadrowski, K., Naeem, S., Niinemets, Ü., Nöllert, S., Nüske, A., Ogaya, R., Oleksyn, J., Onipchenko, V. G., Onoda, Y., Ordoñez, J., Overbeck, G., Ozinga, W. A., Patiño, S., Paula, S., Pausas, J. G., Peñuelas, J., Phillips, O. L., Pillar, V., Poorter, H., Poorter, L., Poschlod, P., Prinzing, A., Proulx, R., Rammig, A., Reinsch, S., Reu, B., Sack, L., Salgado-Negret, B., Sardans, J., Shiodera, S., Shipley, B., Siefert, A., Sosinski, E., Soussana, J. F., Swaine, E., Swenson, N., Thompson, K., Thornton, P., Waldram, M., Weiher, E., White, M., White, S., Wright, S. J., Yguel, B., Zaehle, S., Zanne, A. E., and Wirth, C.: TRY - a global database of plant traits, Global Change Biol., 17, 2905-2935, 2011.

Klein Goldewijk, K. and Batjes, J. J.: A hundred year (1890-1990) database for integrated environmental assessments (HYDE, version 1.1), Bilthoven, the Netherlands, 1997.

Knorr, W.: Annual and interannual $\mathrm{CO}_{2}$ exchanges of the terrestrial biosphere: process-based simulations and uncertainties, Global Ecol. Biogeogr., 9, 225-252, 2000.
Kottek, M., Grieser, J., Beck, C., Rudolf, B., and Rubel, F.: World Map of the Köppen-Geiger climate classification updated, Meteorol. Z., 15, 259-263, 2006.

Krinner, G., Viovy, N., de Noblet-Ducoudré, N., Ogeé, J., Polcher, J., Friedlingstein, P., Ciais, P., Sitch, S., and Prentice, I. C.: A dynamic global vegetation model for studies of the coupled atmosphere-biosphere system, Global Biogeochem. Cy., 19, GB1015, doi:10.1029/2003GB002199, 2005.

Lawrence, D. M., Oleson, K. W., Flanner, M. G., Thornton, P. E., Swenson, S. C., Lawrence, P. J., Zeng, X., Yang, Z. L., Levis, S., Sakaguchi, K., Bonan, G. B., and Slater, A. G.: Parameterization Improvements and Functional and Structural Advances in Version 4 of the Community Land Model, Journal of Advances in Modeling Earth Systems, 3, M03001, doi:10.1029/2011MS000045, 2011.

Lawrence, P. J. and Chase, T. N.: Representing a new MODIS consistent land surface in the Community Land Model (CLM 3.0): Part 1 Generating MODIS Consistent Land Surface Parameters, J. Geophys. Res., 112, G01023, doi:10.1029/2006JG000168, 2007.

Loveland, T. R. and Belward, A. S.: The IGBP-DIS global $1 \mathrm{~km}$ land cover data set, DISCover: First results, Int. J. Remote Sens., 18, 3289-3295, 1997.

Monfreda, C., Ramankutty, N., and Foley, J. A.: Farming the planet: 2. Geographic distribution of crop areas, yields, physiological types, and net primary production in the year 2000, Global Biogeochem. Cy., 22, GB1022, doi:10.1029/2007GB002947, 2008.

Morton, D. C., Nagol, J., Carabajal, C. C., Rosette, J., Palace, M., Cook, B. D., Vermote, E. F., Harding, D. J., and North, P. R. J.: Amazon forests maintain consistent canopy structure and greenness during the dry season, Nature, 506, 221-224, 2014.

Myneni, R. B., Yang, W., Nemani, R. R., Huete, A. R., Dickinson, R. E., Knyazikhin, Y., Didan, K., Fu, R., Negron Juarez, R. I., Saatchi, S. S., Hashimoto, H., Shabanov, N. V., Tan, B., Ratana, P., Privette, J. L., Morisette, J. T., Vermote, E. F., Roy, D. P., Wolfe, R. E., Fiedl, M. A., Running, S. W., Votava, P., ElSaleous, N., Devadiga, S., Su, Y., and Salomonson, V. V.: Large seasonal swings in leaf area of Amazon rainforests, P. Natl. Acad. Sci. USA, 104, 4820-4823, 2007.

Neumann, K., Herold, M., Hartley, A., and Schmullius, C.: Comparative assessment of CORINE2000 and GLC2000: Spatial analysis of land cover data for Europe, Journal of Applied Earth Observation and Geoinformation, 9, 425-437, 2007.

Olson, D. M., Dinerstein, E., Wikramanaye, E. D., Burgess, N. D., Powell, G. V. N., Underwood, E. C., D’Amico, J. A., Itoua, I., Strand, H. E., Morrison, J. C., Loucks, C. J., Allnutt, T. F., Ricketts, T. H., Kura, Y., Lamoreux, J. F., Wettengel, W. W., Hedao, P., and Kassem, K. R.: Terrestrial ecoregions of the world: A new map of life on Earth, Bioscience, 51, 933-938, 2001.

Olson, J., Watts, J. A., and Allison, L. J.: Carbon in Live Vegetation of Major World Ecosystems, ORNL-5862, Oak Ridge National Laboratory, Oak Ridge, Tennessee, 164 pp., 1983.

Ottlé, C., Lescure, J., Maignan, F., Poulter, B., Wang, T., and Delbart, N.: Use of various remote sensing land cover products for plant functional type mapping over Siberia, Earth Syst. Sci. Data, 5, 331-348, doi:10.5194/essd-5-331-2013, 2013.

Pacifico, F., Harrison, S. P., Jones, C. D., Arneth, A., Sitch, S., Weedon, G. P., Barkley, M. P., Palmer, P. I., Serça, D., Potosnak, M., Fu, T.-M., Goldstein, A., Bai, J., and Schurgers, G.: Evaluation 
of a photosynthesis-based biogenic isoprene emission scheme in JULES and simulation of isoprene emissions under presentday climate conditions, Atmos. Chem. Phys., 11, 4371-4389, doi:10.5194/acp-11-4371-2011, 2011.

Pavlick, R., Drewry, D. T., Bohn, K., Reu, B., and Kleidon, A.: The Jena Diversity-Dynamic Global Vegetation Model (JeDiDGVM): a diverse approach to representing terrestrial biogeography and biogeochemistry based on plant functional trade-offs, Biogeosciences, 10, 4137-4177, doi:10.5194/bg-10-4137-2013, 2013.

Peel, M. C., Finlayson, B. L., and McMahon, T. A.: Updated world map of the Köppen-Geiger climate classification, Hydrol. Earth Syst. Sci., 11, 1633-1644, doi:10.5194/hess-11-1633-2007, 2007.

Pongratz, J., Reick, C. H., Raddutz, T., and Claussen, M.: Effects of anthropogenic land cover change on the carbon cycle of the last millennium, Global Biogeochem. Cy., 23, GB4001, doi:10.1029/2009GB003488, 2009.

Poulter, B. and Cramer, W.: Satellite remote sensing of tropical forest canopies and their seasonal dynamics, Int. J. Remote Sens., 30, 6575-6590, 2009.

Poulter, B., Ciais, P., Hodson, E., Lischke, H., Maignan, F., Plummer, S., and Zimmermann, N. E.: Plant functional type mapping for earth system models, Geosci. Model Dev., 4, 993-1010, doi:10.5194/gmd-4-993-2011, 2011.

Radoux, J., Lemarche, C., Van Bogaert, E., Bontemps, S., Brockmann, C., and Defourny, P.: Automated Training Sample Extraction for Global Land Cover Mapping, Remote Sensing, 6, 39653987, 2014.

Ramankutty, N. and Foley, J. A.: Characterizing patterns of global land use: An analysis of global croplands data, Global Biogeochem. Cy., 12, 667-685, 1998.

Ramankutty, N., Evan, A. T., Monfreda, C., and Foley, J. A.: Farming the planet: 1. Geographic distribution of global agricultural lands in the year 2000, Global Biogeochem. Cy., 22, GB1003, doi:10.1029/2007GB002952, 2008.

Reich, P. B. and Borchert, R.: Water stress and tree phenology in a tropical dry forest in the lowlands of Costa Rica, J. Ecol., 72, 61-74, 1984.

Reick, C. H., Raddatz, T., Brovkin, V., and Gayler, V.: Representation of natural and anthropogenic land cover change in MPIESM, Journal of Advances in Modeling Earth Systems, 5, 1-24, 2013.

Ryan, C. M., Williams, M., Hill, T. C., Grace, J., and Woodhouse, I. H.: Assessing the phenology of southern tropical Africa: A comparison of hemispherical photography, scatterometry, and optical/NIR remote sensing, IEEE T. Geosci. Remote, 52, 519-528, 2014.

Scheiter, S. and Higgins, S. I.: Impacts of climate change on the vegetation of Africa: an adaptive dynamic vegetation modelling approach, Global Change Biol., 15, 2224-2246, 2009.
Schroeder, R., McDonald, K., Chan, S., Chapman, B., Podest, E., Bohn, T., Jones, L., Kimball, J., Zimmermann, R., and Küppers, M.: Development and evaluation of a multi-year global inundated area dataset derived from combined active/passive microwave remote sensing, in preparation, 2015.

Sellers, P., Randall, D. A., Collatz, G. J., Berry, J. A., Field, C. B., Dazlich, D., Zhang, C., Collelo, G. D., and Bounoua, L.: A revised land surface parameterization $(\mathrm{SiB} 2)$ for atmospheric GCMs. Part I: Model formulation, J. Climate, 9, 676-705, 1996.

Sitch, S., Smith, B., Prentice, I. C., Arneth, A., Bondeau, A., Cramer, W., Kaplan, J. O., Levis, S., Lucht, W., Sykes, M. T., Thonicke, K., and Venevsky, S.: Evaluation of ecosystem dynamics, plant geography and terrestrial carbon cycling in the LPJ dynamic global vegetation model, Global Change Biol., 9, 161185, 2003.

Still, C. J., Berry, J. A., Collatz, G. J., and DeFries, R.: Global distribution of $\mathrm{C} 3$ and $\mathrm{C} 4$ vegetation: Carbon cycle implications, Global Biogeochem. Cy., 17, 6.1-6.14, 2003.

Tsendbazar, N. E., de Bruin, S., and Herold, M.: Assessing global land cover reference datasets for different user communities, ISPRS Journal of Photogrammetry and Remote Sensing, 103, 93114, 2014.

Tuanmu, M.-N. and Jetz, W.: A global 1-km consensus land-cover product for biodiversity and ecosystem modelling, Global Ecol. Biogeogr., 9, 1031-1045, 2014.

Ustin, S. L. and Gamon, J. A.: Remote sensing of plant functional types, New Phytol., 186, 795-816, 2010.

Verant, S., Laval, K., Polcher, J., and De Castro, M.: Sensitivity of the continental hydrological cycle to the spatial resolution over the Iberian Peninsula, J. Hydrometeorol., 5, 267-285, 2004.

Wilson, M. F. and Henderson-Sellers, A.: A global archive of land cover and soils data for use in general circulation climate models, J. Climatol., 5, 119-143, 1985.

Wullschleger, S. D., Epstein, H. E., Box, E. O., Euskirchen, E. S., Goswami, S., Iverson, C. M., Kattge, J., Norby, R. J., van Bodegom, P. M., and Xu, X.: Plant functional types in Earth system models: past experiences and future directions for application of dynamic vegetation models in high-latitude ecosystems, Ann. Bot., 114, 1-16, 2014.

Yue, C., Ciais, P., Cadule, P., Thonicke, K., Archibald, S., Poulter, B., Hao, W. M., Hantson, S., Mouillot, F., Friedlingstein, P., Maignan, F., and Viovy, N.: Modelling the role of fires in the terrestrial carbon balance by incorporating SPITFIRE into the global vegetation model ORCHIDEE - Part 1: simulating historical global burned area and fire regimes, Geosci. Model Dev., 7, 2747-2767, doi:10.5194/gmd-7-2747-2014, 2014. 